\title{
Bullying nas aulas de educação física
}

Flavia Fernandes de Oliveira* Sebastião Josué Votre**

\begin{abstract}
Resumo: Neste ensaio analisamos ocorrências de bullying como um comportamento "cruel, intrínseco nas relações interpessoais, em que os mais fortes convertem os mais frágeis em objetos de diversão e prazer, através de brincadeiras que disfarçam o propósito de maltratar e intimidar" (FANTE 2005). Com Scott (2005), discutimos alternativas no trato com o diferente. Relatamos e analisamos alguns casos típicos deste fenômeno, ocorridos com meninas e meninos nas aulas de educação física da escola pública do Rio de Janeiro. Concluímos que esse comportamento está inserido em conjunturas culturais e sociais e que as aulas de educação física reproduzem o contexto que os favorece.

Palavras-chave: Bullying ${ }^{1}$. Identidade de gênero. Ensino.

Preconceito. Transtorno de comportamento.
\end{abstract}

\section{Introdução}

Este trabalho tem como intuito trazer uma discussão acerca do fenômeno bullying nas escolas, como o mesmo se dá e se caracteriza, em sua inter-relação com a categoria gênero, nas aulas de educação física. O fenômeno bullying ainda é muito pouco estudado no Brasil, e na educação física ainda não se encontra quase nada a respeito do assunto. Com este estudo, queremos dar uma pequena contribuição teórica e empírica sobre o assunto, que sempre existiu, porém de forma ainda não suficientemente visibilizada. $\mathrm{O}$ bullying $^{2}$

\footnotetext{
Mestranda em Educação Física no Programa de Pós-Graduação em Educação Física da Universidade Gama Filho. E-mail: tabininha@terra.com.br

Universidade Gama Filho. E-mail tabininha@ dera.com.br ão Física da Universidade Professor Titular do Programa de Pós-Graduação em Educação Física da Universidade 1 Gama Filho. E-mail: sebastianovotre@ $@$

Bully, bullied, bullying (registrado a primeira vez em inglês em 1710): to treat abusevely, to affect by means of force or coercion, to use browbeating language or behavior, to intimidade (tratar abusivamente, afetar pela força ou coerção, usar linguagem ou comportamento amedrontador, intimidar) conforme Merriam-Webster's Collegiate Dictionary.
}

Movimento, Porto Alegre, v.12, n. 02, p. 173-197, maio/agosto de 2006. 
significa discriminação dos indivíduos por membros de seu grupo de convívio, e se manifesta em vários graus de intensidade, podendo causar exclusão dos mesmos. Este fenômeno, na conceituação de Fante (2005, p. 29): "É um comportamento cruel, intrínseco nas relações interpessoais, em que os mais fortes convertem os mais frágeis em objetos de diversão e prazer, através de brincadeiras que disfarçam o propósito de maltratar e intimidar".

O conceito mapeia o universo dessa tirania de forma bastante precisa: é um comportamento cruel, portanto marcado pela intencionalidade em atingir objetivos eticamente condenados; é intrínseco nas relações interpessoais, e que pode verificar-se sempre que duas ou mais pessoas interagem, convivem, compartilham espaço de qualquer natureza: trabalho, estudo, lazer, jogo, esporte, brincadeira; é assimétrico, perpetrado pelos mais fortes, mais velhos, detentores de mais poder, de mais controle sobre os demais; os mais frágeis, mais novos, menos poderosos, são convertidos em objetos de diversão e prazer, de modo a provocar o riso, a galhofa, a ironia, o sarcasmo; o instrumento de tortura é a brincadeira verbal, o chiste, a anedota, o apelido, ou a ação aparentemente inocente e sem malícia, que disfarça, esconde, escamoteia o propósito de maltratar, desautorizar, humilhar e intimidar.

Segundo nossa percepção, é a mais primária forma de violência, que pode manifestar-se por palavras, gestos e ações, e tem na linguagem gestual e verbal sua concretização mais comum, pois geralmente começa pela chacota e humilhação verbal, podendo ou não vir acompanhada de ações que discriminam e atemorizam. Representa um perigo constante na família e, mais ainda, na escola. Enquanto em casa é mais comum os pais flagrarem os filhos em cenas de crudelização através de apelidos ou ameaças, na escola é quase sempre imperceptível pelos educadores, porque a violência linguageira, as ameaças de molestação física e as próprias ações violentas se dão longe de seus olhos e ouvidos e, o que é pior, geralmente não deixam marcas no corpo das pessoas molestadas. Tende a ocorrer em contextos relativamente isolados, distantes das

Movimento, Porto Alegre, v.12, n. 02, p. 173-197, maio/agosto de 2006. 
autoridades educacionais, em ambientes em que a vítima não está junto das pessoas que poderiam defendê-la, não raro está sozinha, é mais frágil e tem menos força do que seus agressores e com isso não tem alternativas ou recursos para defender-se.

O bullying verbal baseia-se no realismo linguiístico, no sentido de que as vítimas são apelidadas, normalmente, a partir de um traço físico, de performance, ou psicológico, que as diferencia dos demais e que o apelido põe em destaque, de forma caricatural. Esse traço é reanalisado, pelos autores da violência, como uma degeneração, ou ao menos como um desvio negativo, face à norma, de modo que o uso do epíteto ou apelido atinge diretamente a vítima, ridicularizando-a, no sentido de torná-la objeto de riso, chacota, mal-dizer e escárnio. Os rótulos discriminadores, de base metafórica, são criativos, provocam o riso e a diversão dos circunstantes, e se não fossem trágicos, poderiam ser considerados manifestações da arte da linguagem na interação cotidiana ${ }^{3}$.

Bourdieu (1996, p. 61), tomando como base as pesquisas clássicas de Austin e Searle sobre atos de linguagem, e especificamente sobre o efeito dos atos ilocutórios, insiste na "análise das condições sociais de funcionamento dos enunciados performativos", que funcionam sempre que aquele que os produz tem autoridade ou poder para fazê-lo. Ora, é exatamente o que se passa com o bullying. Seus autores sentem-se no direito de assim proceder, porque são os mais fortes, mais bonitos, mais espertos, detentores de mais poder no grupo, mais influentes, mais ricos. Já as vítimas comungam traços negativos: mais pobres, mais feias, mais afastadas do padrão de prestígio.

${ }^{3}$ A título de ilustração do caráter criativo e imagético do bullying, citamos o caso de uma menina, de boca acima do tamanho normal, que é chamada de vaso sanitário, de um garoto orelhudo, chamado fusquinha de portas abertas, do garoto gordo e narigudo, que é o tromba de elefante, do menino portador de olheira funda, que é chamado de morreu, dos garotos com trejeitos afeminados, que são chamados de pit bitoca, das meninas com alguns traços masculinos, que são apelidadas sapata, sapato, além dos apelidos clássicos, como Maria João.

Movimento, Porto Alegre, v.12, n. 02, p. 173-197, maio/agosto de 2006. 


\section{0 fenômeno bullying na escola}

Em uma pesquisa realizada pela $\mathrm{Abrapia}^{4} \mathrm{em} 2002$, em onze escolas situadas no município do Rio de Janeiro, duas particulares e nove públicas, de $5^{\mathrm{a}}$ a $8^{\mathrm{a}}$ séries, foram ouvidos 5.800 estudantes. Segundo a Nós da Escola (2003, p. 13) ${ }^{5}$ :

Desse total, 40,5\% dos estudantes admitiram que estiveram diretamente envolvidos em atos de bullying em 2002, sendo que 16,9\% se identificaram apenas como tendo sido alvos; $12,7 \%$, como autores; e 10,9\%, autores e alvos. Os $57,5 \%$ restantes negaram ter participado de situações de bullying.

É notório que este fenômeno, para os alunos, não é visto como algo alarmante, pois os autores da molestação alegam que estão apenas brincando; e até mesmo aquelas pessoas que são vitimas, que sofrem agressão e/ou abusos por partes dos/das colegas não os denunciam, provavelmente com medo de represálias dos mesmos. Para Aramis Lopes, (2003, p. 13): pediatra e coordenador da pesquisa, os dados são semelhantes aos encontrados em outros países e revelam um quadro nada animador "Essa questão é uma preocupação mundial; mesmo porque não há como prever nem como avaliar a gravidade das experiências de bullying, como autor ou como alvo, na vida de cada criança ou jovem".

Segundo os psicólogos sociais, a agressão seria um comportamento anti-social, que para Rodrigues (2006), tem a intenção de causar danos, físicos ou psicológicos, em outro organismo ou objeto. "[...] a intencionalidade da ação por parte do agente da agressão, e que só se caracteriza como agressivo o ato que deliberadamente se propõe a infligir um dano a alguém".

${ }^{4}$ Associação Brasileira Multiprofissional de Proteção à Infância e à Adolescência

${ }^{5}$ Revista da Prefeitura do Rio de Janeiro - Educação MULTIRIO, que publicou o artigo intitulado 'Lembranças que não deixam saudades'.

Movimento, Porto Alegre, v.12, n. 02, p. 173-197, maio/agosto de 2006. 
Os psicólogos costumam dividir em dois tipos a agressão humana. Para Myers (2000), a agressão hostil, que para nós está diretamente associada ao bullying, deriva da raiva e tem o objetivo de intimidar e ferir; já a agressão instrumental, que pode relacionar-se ao fenômeno indiretamente, visa a fazer mal apenas como meio de alcançar outro fim, ou seja, para este autor a agressão hostil é intrinsecamente 'ruim', enquanto a agressão instrumental não o é necessariamente.

Portanto o bullying pode ser caracterizado pelos dois tipos de agressão, sendo que para este caso a agressão instrumental não é caracterizada como boa, mesmo que se efetive com intuito de atingir um objetivo supostamente bom, como, por exemplo, apelidar algum colega para chamar atenção dos professores, ou apelidar um colega de 'Nerd', 'CDF', por ele ser o mais inteligente da turma. Porém o tipo de agressão que predomina no fenômeno é a hostil, que é como se inicia o fenômeno, como quando o agressor apelida alguém, para salientar algum tipo de deficiência que o mesmo apresenta, e o chama de 'Quatro olho' por usar óculos; este é um caso de comum entre os alunos, que pode redundar em grande comprometimento emocional na pessoa que está sendo vitimizada.

É comum vermos no espaço escolar a manifestação de agressão, talvez mais acentuada hoje do que se observava há algumas décadas, quando a escola era regida com base na ordem e disciplina, nas sanções e punições. O que se via nas escolas dessa época era o que Foucault (2003) chamava corpos dóceis, no sentido de que os corpos eram transformados pelas instituições, através de um disciplinamento sistemático, o que não quer dizer que eram todos corpos obedientes, como diz Veiga-Neto (2004), pois que nem todos são igualmente disciplinados, embora o poder seja imposto a todos, sendo que a cada corpo e a cada saber, este poder se manifesta de uma forma particular.

Atualmente a escola está um pouco menos atenta à questão

Movimento, Porto Alegre, v.12, n. 02, p. 173-197, maio/agosto de 2006. 
da punição e das sanções, pois o sistema educacional se tornou mais sensível aos reclamos da cidadania dos alunos e passou a ser vigiado, pela consciência dos direitos, mais agudos na sociedade atual, como o Estatuto da Criança e do Adolescente, onde se lê que: "Nenhuma criança ou adolescente será objeto de qualquer forma de negligência, discriminação, exploração, violência, crueldade e opressão, sendo punido na forma da lei qualquer atentado, por ação ou omissão, aos seus direitos fundamentais".

O lado irônico do estatuto é que o mesmo está concentrado nas possíveis ações dos educadores, e as maiores barbaridades se dão entre os próprios colegas, mas essa face do problema não é contemplada no texto legal.

Os direitos fundamentais, ora consagrados nas leis de proteção à criança e ao adolescente, à família e à sociedade, compreendem: direito à vida, à saúde, à alimentação, à educação, ao esporte, ao lazer, à profissionalização, à cultura, à dignidade, ao respeito, à liberdade e à convivência familiar e comunitária. Com isto, a escola que antes poderia caracterizar-se como repressora, comportamentalista e formadora, hoje, ao menos em tese, é somente formadora.

Com esta nova vigilância no sistema educacional ficou mais fácil aos alunos garantirem seus direitos face à instituição e, em compensação, ficou mais difícil para o professor perceber quando há comportamentos imorais ou antiéticos entre os alunos, pois a lei está centrada em garantir justiça apenas no plano vertical, a exemplo do que se lê no Capítulo IV, do artigo 53 do Estatuto já referido: "A criança e o adolescente têm direito à educação, visando ao pleno desenvolvimento de sua pessoa, preparo para o exercício da cidadania e qualificação para o trabalho, assegurando-selhes o direito de serem respeitados por seus educadores".

A convivência dos alunos com situações de bullying pode resultar em danos irreparáveis às vítimas, acarretando, segundo Fante (2005), prejuízos em suas vidas futuras, em suas relações no 
trabalho, em sua futura constituição familiar e na criação de filhos, além de prejuízos para a sua saúde física e mental. Há estudos que comprovam que aqueles que vivem situações de bullying podem ter comprometimentos, como o rendimento escolar inferior, e também o desenvolvimento social, emocional e psíquico atingidos.

Em casos extremos, algumas vítimas preferem suicidar-se a continuar agüentando tal perseguição. É o caso que vem sendo divulgado pela mídia de suicídio de alunos nas escolas, e até mesmo massacre em massa, como foi o caso da Escola Colombine, em Littleton, Colorado em 1999, onde dois adolescentes mataram 12 colegas, um professor e deixaram dezenas de feridos. (FANTE, 2005, p. 80)

A escola, além de templo da educação e casa do saber, pode desempenhar também o papel de cenário propício ao surgimento de subcomunidades voltadas ao bullying, à tortura e ao sofrimento de seus pares. Entre tais subcomunidades, avulta a da educação física, esporte e lazer.

\subsection{Bullying nas aulas de educação física}

Em trabalho intitulado "Discriminação de Gênero nas aulas de Educação Física", apresentado no Congresso Brasileiro de Ciências do Esporte (FERNANDES, 2005), verificamos manifestações deste fenômeno através de pesquisa de campo, realizada via entrevista com grupo focal, com seis crianças, três do sexo masculino e três do sexo feminino, alunos da $4^{\mathrm{a}}$ série do ensino fundamental público do município do Rio de Janeiro. A pergunta norteadora foi: - quais são os tipos de violência e discriminação existentes entre meninos e meninas, nas aulas mistas de educação física? Os alunos e as alunas discutiram com interesse sobre o que acontecia nas suas aulas no que concerne a esse tipo de abuso. A principal evidência foi da agressividade dos meninos, manifestada através de palavras e atos, a ponto de uma menina, durante a fala, se queixar dos apelidos, das ofensas, das atitudes e ações

Movimento, Porto Alegre, v.12, n. 02, p. 173-197, maio/agosto de 2006. 
dos meninos: "[...] muitas das vezes as pessoas acabam se machucando, né, porque os meninos são um pouco mais agressivos".

Agressividade e competitividade se associaram fortemente aos meninos, enquanto para as meninas predominou a fragilidade. Para Myers (2000) a agressividade refere-se ao ato de ferir o outro, física ou simbolicamente, e as pesquisas sugerem que os homens, mais voltados às atividades tipicamente masculinas, como caçar, lutar e guerrear, são mais propensos à agressividade do que as mulheres. Isto não quer dizer que o comportamento agressivo não apareça nas meninas, pois elas também o são, principalmente entre si.

No estudo aqui referido, o intuito era revelar os tipos de violência e discriminação de gênero existentes nas aulas de educação física mista, partindo da turma de quarta série, que é caracterizada por alunos da faixa etária a partir do 10 anos. Escolhemos esta faixa e série porque, segundo Aberastury, (1992, p. 84), entre os 10 e os 11 anos tanto os meninos quanto as meninas tendem a formar grupos: "Os meninos têm meninos à sua volta $\mathrm{e}$ as meninas têm meninas, porque necessitam se conhecer e aprender as funções de cada sexo". E é nítido também que é a partir desta faixa etária que as crianças tendem a desenvolver mais explicitamente os comportamentos de bullying, ou a serem molestadas pelos agressores.

Esses grupos podem ser prejudiciais ou não à formação da criança, se nos reportarmos a Scott $(2005$, p. 15), que diz que "Identidade de um grupo define indivíduos e renega a expressão ou percepção plena de sua individualidade". A fidelidade ao grupo pode chegar a tolher ou prejudicar o desenvolvimento pleno do indivíduo. As identidades de grupo são formas de comportamento e manifestação próprias do mesmo, sem que necessariamente os indivíduos se dêem conta do que está ocorrendo. Por exemplo, se $o$ ato de agressão durante um jogo entre meninos e meninas se tornar normal, eles podem, de forma não intencional, mas aciden-

Movimento, Porto Alegre, v.12, n. 02, p. 173-197, maio/agosto de 2006. 
talmente, selecionar uma vitima, para ser alvo de deboches, de ameaças e até mesmo de agressão física; pode ser que esteja ocorrendo o fenômeno bullying, sem que o professor ou professora perceba, e mesmo sem que cada membro do grupo, enquanto indivíduo, tome consciência do ato em que está envolvido.

Devido às diferenças de habilidades entre meninos e meninas, é comum vermos então surgirem conflitos de gênero, pois é inconscientemente que as crianças incorporam, através do cotidiano escolar, as identidades que, para Louro (2003) são "identidades de gênero" - aqui retraduzidas como identidades de grupo quando os sujeitos se identificam, social e historicamente, como masculinos ou femininos, fortes ou frágeis, corajosos ou medrosos. Essas identidades são manifestações comportamentais, como os gestos, os movimentos e os efeitos de sentido que, através do compartilhamento, imprimem, reproduzem e reforçam consciência das diferenças e do poder a elas associado.

Quando falamos em lutar por uma sociedade igualitária, temos em vista um contexto em que todos temos direitos iguais, sem que homens ou mulheres sofram preconceitos por serem diferentes, quer na força física, destreza, habilidade, flexibilidade e velocidade, quer na pertença a determinada classe, raça, religião ou idade.

\subsection{Análise de alguns relatos de bullying na educação física}

Inicialmente, vamos apresentar um relato sui generis, citado em Fante (2005, p. 35). Em suas pesquisas, exemplificando o fenômeno, a autora nos apresenta um depoimento de uma aluna da educação física, atravessado por gênero na variante poder, em que a menina é alvo de bullying duplo, sui generis por incluir professores, na forma de difamação, e por colegas, na forma de múltiplos apelidos: 'baixinha, frágil, inútil, que não serve para nada':

Minha vida escolar não é a melhor. Gosto muito dos professores, mas de umas semanas para cá eles andam me difamando, por causa de um

Movimento, Porto Alegre, v.12, n. 02, p. 173-197, maio/agosto de 2006. 
trabalho escolar. Estou sendo rejeitada por algumas pessoas da minha classe. Na aula de educação física, dizem que sou baixinha e frágil, então não sirvo para nada [...] (aluna da $6^{a}$ série, 12 anos).

O relato é sintomático, pelo nível da avaliação do quadro, pois esta aluna denuncia, explicitamente, a falta de qualidade de sua vida escolar: ela está sendo alvo de discriminação por parte dos professores, que a difamam por causa de seu desempenho; a rejeição de algumas pessoas da classe pode estar associada a outro grupo discente, que explora a difamação; na educação física, para completar sua desgraça, ela é objeto de bullying dos colegas, seja por ela apresentar características físicas que destoam dos demais colegas, quer ainda por ser baixinha e frágil; a síntese da avaliação é patética: então não serve para nada . O sentir-se rejeitada nas aulas de educação física é facilmente explicável, pois a disciplina, até bem pouco tempo (e ainda hoje), se pautava por um modelo reducionista em que o corpo, a aptidão física e o desempenho eram os objetivos mais importantes. Nesse quadro, não havia espaço para as meninas 'baixinhas e frágeis', sobretudo quando a essas características somava-se a falta de habilidade; elas não tinham vez, não jogavam e nem praticavam esportes com suas colegas meninas e muito menos com os meninos. A prática esportiva privilegiava aquelas que tinham um bom desempenho e que eram aptas a praticar aquelas modalidades esportivas associadas à velocidade, força, impacto e resistência.

Estudos demonstram que na maioria dos casos de bullying as agressões são provocadas por rapazes, porém o sexo das vitimas varia. Como recorte inicial deste estudo, iremos apresentar e analisar relatos ${ }^{6}$ de quatro manifestações de bullying na educação física, em diferentes escolas, duas em que as vitimas são meninas e duas em que os meninos passam pelo ritual do sacrifício.

${ }^{6}$ Os relatos são da co-autora deste trabalho.

Movimento, Porto Alegre, v.12, n. 02, p. 173-197, maio/agosto de 2006. 
O primeiro é um caso típico do fenômeno bullying, que ocorreu com $\mathrm{Carol}^{7}$ em escola pública da Zona Oeste do Município do Rio de Janeiro:

Carol é uma aluna calma e tranqüila, que estava em uma turma de progressão; os outros alunos tinham um comportamento bastante dife rente do dela, porém estavam todos na mesma turma, pois tinham dificuldades de aprender. Essa turma, em especial, tinha um comportamento bastante agressivo, tanto os meninos, quanto às meninas, e nas aulas de educação física eles eram violentos e agressivos uns com os outros. Carol, com toda dificuldade de se relacionar com os outros colegas, se prejudicava sempre. Quando os membros do grupo meninos e meninas - descobriram que ela era calma e tranqüila, e principalmente frágil, começaram todos a implicar com ela. A professora não se deu conta, pois como a turma era bastante violenta, todo o tempo os meninos e meninas estavam brigando, na sala, nos corredores e até mesmo nos banheiros da escola. E ela não percebeu o que estava acontecendo com a menina. Foi quando Carol começou a faltar às aulas, chegando a ficar semanas sem ir à escola. Eu, como professora de educação físi$c a$, notei que ela estava faltando às aulas, $e$ perguntei à professora o que havia com Carol, e ela não soube me responder; a única coisa que ela me disse foi que era assim mesmo, ninguém daquela turma queria nada, era por isso que eles abandonavam a escola. Passadas umas três semanas, a mãe de Carol veio à escola para conversar com a direção, para saber o que estava acontecendo, e por que era que nun-

7 Os nomes das vítimas de bullying dos relatos são fictícios.

Movimento, Porto Alegre, v.12, n. 02, p. 173-197, maio/agosto de 2006. 
ca tinha aula para sua filha. Carol estava chorando sem parar e a mãe, a professora e a diretora perguntavam a ela o que estava acontecendo. Foi então que, chorando, ela disse que os colegas de turma em geral não gostavam dela, que a tratavam por apelidos que ela tinha vergonha de falar, e que dois colegas, um menino e uma menina da turma, estavam cobrando dela um real por dia para ela entrar na escola; caso ela não tivesse o dinheiro, ela não poderia entrar na escola, e se entrasse na escola, todos iriam bater nela. Com isto, todos os dias Carol ia até a porta da escola e voltava para casa.

Devemos salientar que este relato resume uma situação prototípica em nossas instituições de ensino. Trata-se de um quadro de constrangimento comum nas escolas, em que as crianças, em forma de brincadeira, discriminam, agridem e principalmente excluem colegas. Se para muitos professores, de tão comum parece normal esta prática das crianças, vale ponderar que a maneira cruel como elas agem é prejudicial para a formação da auto-estima de cada indivíduo, para o senso de justiça dos agressores, e para o senso de cidadania, dos agredidos, comprometendo o projeto de uma sociedade justa, pois a violência nas escolas pode acarretar danos irreversíveis aos futuros cidadãos ${ }^{8}$.

Enderle (1985) diz que a escola representa para a criança a entrada em um mundo diferente da família, onde aparecem as noções explícitas de ordem, dever, disciplina e, principalmente, silêncio. Isto não quer dizer, segundo a autora, que é somente por causa da escola que a criança apresentará problemas, pois antes da mesma está a família.

8 O imaginário social está povoado de ditados e frases feitas que denotam a extensão
dessa prática e, o que é pior, de sua naturalização na cultura. llustramos com a seguinte: dessa prática e, o que é pior, de sua naturalização na cultura. Ilustramos com a seguinte:
"para os amigos, tudo; para os inimigos, a lei"ou: "para os amigos, tudo; para os inimigos, nem justiça".

Movimento, Porto Alegre, v.12, n. 02, p. 173-197, maio/agosto de 2006. 
A escola estava introduzindo Carol em novo patamar no processo de socialização, durante o qual ela estava começando a sentir-se confrontada por um grupo, onde não encontrava sinais de simpatia, e sim imperavam as regras próprias do grupo.

$$
\begin{aligned}
& \text { A sociedade infantil, nessa fase, é fechada aos } \\
& \text { adultos e por vezes tem matrizes de crueldade. } \\
& \text { As peculiaridades físicas ou idiossincrasias das } \\
& \text { crianças constituem objeto de 'troça'. A críti- } \\
& \text { ca é pessoal e direta. Além da crítica severa, } \\
& \text { surge, também, a capacidade de julgamento, } \\
& \text { estabelece-se a noção de 'justiça' que acaba } \\
& \text { por eliminar o traidor, ou aquele que não obe- } \\
& \text { dece ao código ético imposto pelo } \\
& \text { grupo.(ENDERLE, 1985, p. } 70)
\end{aligned}
$$

Ao observarmos o que acontece com Carol, vemos que os seus colegas de turma fazem parte de um grupo fechado, constituído por uma minoria, que apresentam um código de ética, onde impera um líder, que estabelece as regras, e quem não o respeitar não pode fazer parte deste grupo. Foi exatamente o que aconteceu com Carol, se ela tivesse aceitado pagar o real diário que eles tinham estabelecido a ela, talvez ela entrasse no grupo. Entretanto, ela poderia também ser escolhida pelo grupo para ser a 'bola da vez', ou seja, a permanentemente excluída, discriminada e 'chacoteada'.

Como diz Scott (2005), lidar com a situação de desigualdade é confrontar-se com o paradoxo, que é uma proposição que não pode ser resolvida pelas operações da lógica convencional, e que é falsa e verdadeira ao mesmo tempo. O caso de discriminação contra Carol é um tipo de bullying que não tem interferência dos educadores, no sentido de que, como a sociedade infantil, conforme disse Enderle, é fechada aos adultos, eles não se deram conta do que estava acontecendo com ela, nem que o comportamento hostil de colegas, centrado no preconceito, estava acarretando agressões contínuas à menina, a ponto de expulsá-la da escola.

Estamos tomando preconceito no sentido etimológico do termo, como um conceito previamente formado, de uma pessoa ou

Movimento, Porto Alegre, v.12, n. 02, p. 173-197, maio/agosto de 2006. 
grupo, contra indivíduos ou grupos.

\begin{abstract}
Preconceito é um pré-julgamento negativo de um grupo e de seus membros individuais. $O$ preconceito nos predispõe contra uma pessoa com base apenas no fato de identificarmos a pessoa a um grupo determinado. O preconceito é uma atitude, [...] uma combinação distinta de sentimentos, inclinações para agir e convicções. (MYERS, 2000, p. 182)
\end{abstract}

Para Nunan (2003), o preconceito é histórico e socialmente construído, e o mesmo resulta na discriminação, que é o comportamento, o modo de agir do grupo social, marcado por raiva, rejeição e repulsa. No relacionamento entre os fortes e os fracos, entre os prestigiados e os sem prestígio, entre os meninos e as meninas, estão presentes os conflitos, as resistências e mesmo os mecanismos de exclusão, o que acaba causando atitudes negativas do grupo social ou, até mesmo, dos indivíduos. Segundo Rodrigues (2001), o preconceito pode ser definido como uma atitude hostil ou negativa, com relação a um determinado grupo, não levando, necessariamente, a atos ou comportamentos persecutórios.

Quando estamos nos referindo à esfera do comportamento (expressões verbais hostis, condutas agressivas, etc), fazemos uso do termo discriminação. Neste caso, sentimentos hostis somados a crenças estereotipadas deságuam numa atuação que pode variar de um tratamento diferenciado a expressões verbais de desprezo $e$ a atos manifestos de agressividade. (RODRIGUES, 2001 p. 162).

A discriminação contra Carol, por parte das outras crianças, é um caso típico de ação ilocutória, via palavras, gestos e atitudes de desprezo, porém sem agressão física, mas com ameaças da mesma, caso ela entrasse na escola sem pagar o que eles queriam. Durante esse período de provação ela, sem alternativas, passou a isolar-se dos outros membros da turma, desistindo de freqüentar a escola. Esta, que seria um espaço de socialização, tornara-se para 
ela um não-lugar, um lugar de exclusão.

O segundo exemplo de bullying com meninas aconteceu com Aline em uma turma de quarta série de uma escola pública, também situada na Zona Oeste do município do Rio de Janeiro:

Aline é uma aluna tipicamente diferente das outras alunas de sua turma, ela adora fazer aula de educação física, sempre me ajudou na divisão dos grupos, na disposição dos materiais, quando havia jogo era sempre a primeira menina a ser escolhida, pelos meninos e pelas meninas, porque é uma aluna que apresenta uma excelente habilidade motora, especificamente é ótima jogadora de futebol. Aparentemente, tanto nas aulas de educação física, quanto nas outras disciplinas, não havia nenhum problema com ela. Até que Aline começou a aparecer na escola de cabelos cortados, um corte bem masculino, e então as meninas na sala começaram a chamá-la de Maria João, Aline Sapato, entre outros apelidos, até mesmo porque Aline é uma menina bem diferente das demais da idade dela, pois não possui vaidade, não gosta de usar brincos, e muito menos de se maquiar. Na minha aula de educação física era a mesma coisa, sendo que ela comecou a aparecer na escola com uma toca na cabeça, para não aparecer o corte, foi aí então que eu comecei a perceber que algo de errado estava acontecendo com ela. Quando separei os alunos para escolherem os times, para jogar, nenhum dos alunos a escolheu, e ela aos poucos foi saindo da quadra e indo para arquibancada. Foi então quando eu a chame para conversar e perguntar o que estava acontecendo. Antes de começar o jogo, pergunte aos alunos por que eles não a escolheram para jogar, e sem me responder, um dos meninos que estava escolhendo o time disse: - vem, Aline Sapato, e todos riram, uns até em tom de deboche; foi aí que eu percebi que ela estava sendo

Movimento, Porto Alegre, v.12, n. 02, p. 173-197, maio/agosto de 2006. 
vitima de bullying na turma, e foi quando eu interferi e conversei com eles a respeito. Depois todos jogaram e no final da aula retornei a conversar com Aline, perguntando a ela se ela estava se sentindo incomodada com o corte de cabelo, e quem cortou o cabelo dela e ela me respondeu que ela que quis cortar daquela forma, foi a mãe dela quem cortou o cabelo dela, porém ela estava se sentindo envergonhada, com os apelidos e as brincadeiras dos colegas, e era por isso que estava indo de toca para escola. Conversando com ela e com a professora dela de sala de aula, mostrei o exemplo da própria professora dela, que usa o cabelo curto, e a professora de sala de aula, junto comigo, dissemos a ela que daquele dia em diante ela não iria mais sofrer humilhações por parte dos colegas.

A leitura do relato torna evidente que a menina foi vitima de bullying, pois embora no começo ela parecesse aceita pelo grupo a que pertencia, sempre apresentou alguns aspectos que a distinguiam das demais meninas de sua turma, a exemplo das habilidades motoras excepcionais, semelhantes ou mesmo superioras às de alguns meninos. A impressão é que, progressivamente, Aline foi se tornando alvo de gozação e de brincadeiras maliciosas, que estavam levando a ser rejeitada e, por fim, excluída do grupo, com os inevitáveis danos emocionais, esportivos e educacionais.

Este segundo exemplo configura um caso complexo e mesmo complicado de rejeição, porque Aline já tinha um perfil pouco feminino, em termos de habilidades, e agora, com este traço externo do corte de cabelo, a coisa piorou, mas talvez o apelido já estivesse ativo antes, por ela ser uma menina que sempre realizava as atividades esportivas com ótimo desempenho. Segundo Saffioti (1987, p. 37): "Mulher despachada corre risco de ser tomada como mulher-macho".

Como os estereótipos sexuais são culturalmente dados, pas-

Movimento, Porto Alegre, v.12, n. 02, p. 173-197, maio/agosto de 2006. 
sa a ser considerado normal vermos o menino jogando bola, e meninas brincando de boneca, porém isto não quer dizer que as meninas só vão se interessar pelas atividades que lhes são prédeterminadas pela sociedade. Existem crianças com preferência cultural cruzada, o que se pode dar por várias causas, entre as quais registra-se o reforço em desempenhar os papéis do sexo oposto, as sugestões e insinuações da família:

\begin{abstract}
Algumas meninas ganham caminhõezinhos $e$ ferramentas e jogam futebol ou aprendem carpintaria com o pai (ou mãe). Eles também podem desejar que elas fossem meninos [...] o comportamento masculinizado na menina é muito mais aceito e reforçado do que o comportamento feminilizado no menino. (BEE. 1985, p. 321).
\end{abstract}

Acreditamos que se percebeu a tempo o que estava acontecendo com ela, porque Aline é uma aluna dedicada e que se interessa por todas as atividades físicas, tantas as que são predeterminadas como sendo masculinas como as consideradas femininas, porém o que a diferencia de modo singular das demais colegas é que ela apresenta habilidade superior às outras meninas. Se Aline continuasse a ser alvo dessa perturbação, poderia rebelar-se contra os comentários pejorativos, passar a mostrar falta de interesse em freqüentar a escola. O seu desempenho na escola diminuiria, a sua auto-estima seria ainda mais prejudicada, e ela poderia até abandonar a escola, ela que foi uma aluna que nunca causou problemas às professoras.

O terceiro exemplo é de um menino, Carlos, de 11 anos, de escola pública municipal da Zona Oeste do município do Rio de Janeiro:

Carlos é um aluno aplicado, educado e muito inteligente. É conhecido pelos colegas como o CDF da turma. Durante as aulas, quando a sua professora de sala de aula atribuía tarefas para os alunos, ele era sempre o primeiro a

Movimento, Porto Alegre, v.12, n. 02, p. 173-197, maio/agosto de 2006. 
começar a executá-las, e a terminar as tarefas, com perfeição, antes dos demais; como um bom amigo, também ajudava os que têm mais dificuldades. A única coisa que o incomodava é que ele não gostava de jogar futebol e acabava convivendo pouco com os garotos; com isso, os meninos da turma passaram a caçoar dele, porque além de não jogar futebol, ele se afastava dos meninos e andava mais com as meninas. As brincadeiras agressivas que os meninos da sua classe faziam que não lhe agradavam. Nas aulas de educação física, Carlos sempre participava, tantos nos jogos como nas brincadeiras. Mas quando o tema da aula era futebol, ele pedia para ser o arbitro do jogo, ou então para não participar do jogo. Os colegas de classe, na entrada ou na saída da aula, sempre se organizavam para jogar futebol, na quadra, ou no gramado, mas ele nunca participava, com o argumento de que seus colegas, durante o jogo, sempre brigavam e acabavam agredindo-se uns aos outros, e Carlos não gosta de briga. Os meninos perceberam que ele era diferente deles e colocaram-lhe apelidos que o atingiam no tocante à masculinidade, chamando-o de Pit Bitoca, Boiolinha, Veadinho, Biba e Bicha. Um dia na aula de educação física, em que a professora propôs aula livre, para que eles próprios escolhessem a atividade ou o jogo que iriam realizar, os alunos decidiram jogar um grande queimado. Na hora da escolha dos times, após o 'par ou impar', os meninos começaram rir dele em vez de o escolherem, porque era um jogo de que ele gostava, pois sempre que tinha oportunidades, jogava com as meninas. Como os meninos não o escolheram, as meninas o chamaram, dizendo: 'vem Pit', e ele foi jogar com elas e não contestou, mas como todos estavam caçoando, e xingando muito, ele saiu do jogo e sentou-se na arquibancada. Quando eu perguntei por que ele não estava jogando, e por

Movimento, Porto Alegre, v.12, n. 02, p. 173-197, maio/agosto de 2006. 
que ele não reagia, ele disse que era assim mesmo. Então eu parei a atividade, sentei com a turma, e comecei a discutir, argumentando os apelidos e a discriminação a eles associada. A turma disse: - mas ele é mesmo, não reage. Se não reage, é porque é isso mesmo. Então eu falei a eles que parassem, e que durante as suas aulas não queria mais ouvir apelidos e nenhum tipo de discriminação, nem com Carlos e nem com ninguém.

A estratégia utilizada pela professora, em discutir com a turma as questões das diferenças e tentar convencê-los através do diálogo sobre a obrigação do respeito, da não discriminação do outro durante as aulas, ajudou a minimizar as exclusões nas aulas de educação física, e a desconstrução dos valores dominantes na sociedade de que homem, macho, tem que jogar futebol. A professora levou os alunos a perceberem que era uma injustiça e um abuso de poder o que acontecia com Carlos, e que é injusta expectativa social de que todo menino goste de futebol, embora, desde pequeninos, os meninos sejam estimulados a ficar em vários espaços públicos, jogando em grupo e até mesmo sozinhos, chutado a bola.

Verificamos que a intimidação e agressão ao Carlos chegou ao extremo, pois até meninas o discriminavam; o bullying, neste caso, está relacionado à pratica esportiva. Segundo Vaz (2005) o futebol - no Brasil - é um jogo identificado como sendo masculino, porque as qualidades sociais atribuídas aos homens, como virilidade, agressividade e competitividade, entre outras, são toleradas e estimuladas no jogo de futebol, que é muito praticado, quase exclusivamente por garotos, nos espaços públicos e nas ruas. Segundo o autor:

No caso da prática esportiva, especialmente do futebol, não são apenas as mulheres as discriminadas, mas qualquer um, mulheres e homens, que não se desempenhem satisfatoriamente no jogo tal como é esperado pela lógica dominante, predominantemente masculinizada

Movimento, Porto Alegre, v.12, n. 02, p. 173-197, maio/agosto de 2006. 
no Brasil. O que quer dizer que as mulheres que apresentam uma performance razoável para os padrões masculinos, não serão discriminadas, ao contrario, serão recebidas e enaltecidas pela sua participação. Ao mesmo tempo, homens que não apresentam este desempenho serão vitimas de práticas discriminatórias. Muitas vezes essas discriminações os levam ao abandono das aulas de educação física ou ao envolvimento com outras modalidades esportivas como voleibol e natação, entre outras, ou mesmo a uma outra manifestação da cultura corporal como dança, as lutas ou, ainda, as artes cênicas. (RODRIGUES, 2005, p. 32)

Fante (2005) chama a atenção do profissional de educação, para que fique atento a alunos agressivos ou violentos, zombadores e maldosos, porque em alguns casos o que se poderia interpretar como brincadeiras próprias da idade pode ser fonte de grande constrangimento e sofrimento a colegas mais tímidos, calados ou mais fracos, normalmente mais novos, com prejuízo sócio-educacional e emocional.

O quarto exemplo é relacionado à inclusão de dois meninos, Marcos e Paulo, portadores de deficiência mental leve, numa turma 'normal':

Marcos começou a fazer aula normalmente em uma turma com alunos da idade dele. Ele é da classe especial da escola; os demais alunos da turma, ditos normais, já o conheciam, pois ele é irmão de uma das alunas da turma. A aula de educação física iniciou bem, mesmo porque fiz questão de dizer a todos que na aula daquele dia havia dois colegas da classe especial que iriam fazer aula junto com a turma. Aconteceu que o Marcos não fez questão de participar nas atividades junto com os outros da turma. No momento em que propus um jogo para a turma, vi que todos jogaram, menos Marcos, que não quis jogar. Vi também que sua irmã

Movimento, Porto Alegre, v.12, n. 02, p. 173-197, maio/agosto de 2006. 
parou de jogar e resolveu brincar de corda com ele e mais uma colega. Paulo, por outro lado, interessou-se pelo jogo, do qual tentava participar ativamente. Mas a situação de normalidade no jogo durou pouco, porque assim que o time percebeu que Paulo era diferente, e que durante o jogo não conseguia respeitar as regras, constatou que ele é portador de deficiência mental. Os alunos começaram a rir dele e chacoteá-lo, e como no time em que ele estava jogando os colegas estavam perdendo e não conseguiam jogar, começaram a provocar-me, sem esconder a rejeição e o preconceito, dizendo: - a senhora trouxe um maluco para cá? Põe o maluco pra fora! A aula não é para maluco. Foi então que Paulo, que tem um grau de deficiência quase imperceptível, veio queixarse a mim, dizendo que eles, longe das professoras, só o chamavam pelos termos maluco e doidinho.

Diante daquela situação a professora, parou a aula e convocou todos para discutir as questões de inclusão de Marcos e Paulo, portadores de deficiência. Sentou os alunos e solicitou que conversassem sobre o que estava se passando em relação a Paulo, que se esforçava por participar e era rejeitado. O grupo discutiu longamente, e tirou uma decisão de tentar ajudar o garoto. Nas aulas seguintes, diminuiu a manifestação de rejeição para com Paulo. Podemos perguntar se a estratégia de dialogar, argumentar e denunciar a injustiça da atitude dos colegas mudou de fato as relações entre os alunos, se alterou o quadro para valer, ou se foi só naquele contexto, na frente da professora, que se fez justiça. É impossível responder a esta pergunta, mas a estratégia merece ser testada e aperfeiçoada, dado o poder da argumentação e do debate franco para a revisão de atitudes e práticas sociais. Habermas (2001) prevê, em sua teoria da ação comunicativa, que os que estão prontos e com disposição para serem convencidos tenderão a mudar de atitude e prática após participarem de eventos argumentativos sérios, em que são convidados a refletir sobre a

Movimento, Porto Alegre, v.12, n. 02, p. 173-197, maio/agosto de 2006. 
justiça, justeza e ética de seus comportamentos.

Os quatro casos atestam que o fenômeno bullying transita o tempo todo nesses comportamentos de discriminação, com chacota e agressão seja ela verbal e/ou física. As vítimas da intimidação normalmente enfrentam a molestação sozinhas. Os outros meninos e meninas tendem a ficar do lado dos agressores, temendo ser os próximos da fila, ou fingem que nada viram e permanecem quietos. O abuso pode afetar todo o ambiente da escola, e não apenas os autores da ofensa física e psicológica e seus alvos.

\subsection{Observações preliminares e proposta de intervenção}

Através deste estudo percebe-se que alunas e alunos são vitimas do fenômeno bullying, porém que nem sempre o mesmo é percebido, pelos membros do corpo docente ou pela direção da escola e (arriscamos a afirmar, sem provas) nem mesmo pela família.

O gênero atravessa esta questão nas aulas de educação física, pois, no recorte deste estudo as meninas se tornam um alvo fácil da crueldade linguageira, devido à pequena ou nula participação das mesmas, até bem pouco tempo, nas aulas de educação física. Os meninos, por sua vez, são desqualificados se não mostrarem desempenho à altura da expectativa. A desqualificação e rejeição se dão pelos estereótipos esperados de cada sexo, construídos pela sociedade, segundo os quais as meninas têm que ser graciosas e frágeis, e não devem participar de jogos de impacto ou viris, e os meninos devem ser agressivos.

Bullying é a ponta do iceberg da discriminação, e um indício de o quanto as pessoas estão envolvidas com os estereótipos culturais, que são produzidos conjuntamente por homens e mulheres na sociedade familiar e, sobretudo escolar, em que as crianças e os jovens os acabam reproduzindo. Representa um desafio único para os educadores, que são convidados a afiar o olhar, a melhorar a escuta, atentos aos sinais de injustiça e crueldade e, na linha do

Movimento, Porto Alegre, v.12, n. 02, p. 173-197, maio/agosto de 2006. 
que aqui se fez em cada caso relatado, a interferir pela conversa em grupo, em que se oferecem oportunidades para a reflexão, a tomada de posição e a superação do problema pela ampliação do círculo do nós, pelo alargamento da consciência. Na linha de ação educativa de Stoer e seus colegas, cabe à escola a tarefa de se recontextualizar para favorecer o debate franco, corajoso e objetivo das questões que afligem sua comunidade.

Pensamos que, segundo a orientação de Bernstein (2001) é dever da escola recontextualizar-se e reposicionar-se face a este grave problema, e tirar uma linha firme de conduta moral e ética de modo que fique explícito, no código de ética da escola, discutido e acolhido por professores e alunos, que nenhuma criança ou adolescente pode ser desrespeitada, agredida, ameaçada ou negligenciada, nesse espaço de convívio e formação. Deve-se fazer com que os meninos e as meninas sejam mais tolerantes, e aprendam a compreender as diferenças, para não utilizarem a suas habilidades, dentro da aula de educação física, como meio de violência.

Bullying in Physical Education Classes
Abstract: In this essay, we analyze the phenomenon
of bullying, as a behavior which is "cruel, intrinsic
in interpersonal relationships, by which the strongest
ones convert the fragile ones in object of
entertainment and amusement, through jokes that
hide the goal of mistreat and threat (FANTE 2005)".
Following Scott (2005), we discussed alternatives
in the deal with the different, report and analyze
some prototypical cases of the phenomenon,
verified with girls and boys in physical education
classes, in the public school of Rio de Janeiro. We
conclude that this behavior is inserted in cultural and
social contexts, and that the classes of physical
education reproduce the context favoring them.
Key words: Bullying. Gender identity. Teaching.
Prejudice. Conduct disorder.

Movimento, Porto Alegre, v.12, n. 02, p. 173-197, maio/agosto de 2006. 


\section{Bullying en las clases de Educación Física}

Resumen: En este ensayo analizamos el fenómeno de bullying como un comportamiento "cruel, intrínseco en las relaciones interpersonales, en que los más fuertes convierten a los mas frágiles en objeto de diversión y placer, a través de bromas que mascaran el propósito de maltratar e intimidar" (FANTE 2005). Con Scott (2005), discutimos alternativas en el trato con el diferente. Relatamos e analizamos algunos casos típicos de ese fenómeno, ocurridos en clases de educación física con niñas y niños de la escuela pública de Río de Janeiro. Concluimos que ese comportamiento está inserido en contextos culturales y sociales, e que las clases de educación física reproducen el encuadre que los favorece.

Palabras-clave: Bullying. Identidad de género. Enseñanza. Prejuicio. Trastorno del comportamiento.

\section{REFERÊNCIAS}

ABERASTURY, Arminda. A criança e seus jogos. Porto Alegre: Artmed, 1992. AUSTIN, John L. How to do Things with Words. Oxford: Oxford University, 1978. BEE, Helen. A criança em desenvolvimento. 3. ed. São Paulo: Harbra, 1984. BERNSTEIN, Basil. Das pedagogias aos conhecimentos. Educação, Sociedade \& Culturas, Porto, 2001.

BOURDIEU, P. A economia das trocas lingüísticas: o que falar quer dizer. São Paulo: Edusp, 1996.

ENDERLE, Carmen. Psicologia do desenvolvimento: o processo evolutivo da criança. Porto Alegre: Artmed, 1985.

FANTE, Cleo. Fenômeno bullying: como prevenir a violência nas escolas e educar para paz. 2. ed. Campinas: Verus, 2005.

FOUCAULT, Michel. Vigiar e punir : nascimento da prisão. 27. ed. Petrópolis: Vozes, 2003

HABERMAS, Jürgen. Pensamento pós-metafísico : estudos filosóficos. Rio de Janeiro: Tempo Brasileiro, 1990. 
LOURO, Guacira Lopes. Gênero, sexualidade e educação: uma perspectiva pós-estruturalista. 6. ed. Petrópolis: Vozes, 2003.

MYERS, David G. Psicologia social. Tradução de A. B. Pinheiro de Lemos. Rio de Janeiro: LTC, 2000.

NUNAN, Adriana. Homossexualidade: do preconceito aos padrões de consumo. Rio de Janeiro: Caravansarai, 2003.

OLIVEIRA, Flavia Fernandes de. Discriminação de gênero nas aulas de educação física. In: CONGRESSO BRASILEIRO DE CIÊNCIAS DO ESPORTE E CONGRESSO INTERNACIONAL DE CIÊNCIAS DO ESPORTE, 14., 2005, Porto Alegre. Anais... Rio de Janeiro: UGF, 2005

RODRIGUES, Aroldo; ASSMAR, Eveline Maria Leal; JABLONSKI, Bernardo. Psicologia social. 23. ed. Petrópolis: Vozes, 2005.

RORTY, Richard. Contingência, ironia e solidariedade. Tradução de Nuno Ferreira da Fonseca. Lisboa: Presença, 1994. (Biblioteca de textos universitários. Nova série 6).

SAFFIOTI, Heleieth Iara Bongiovani. O poder do macho. 3. ed. São Paulo: Moderna, 1987.

SCOTT, Joan W. O enigma da igualdade. Revista Estudos Feministas Florianópolis, v. 13, n. 1, p.11-30, jan./abr. 2005.

SEARLE, John R. Reiterating the Differences: a Reply to Derrida. Glyph, Baltimore v. 1, n. 1, p.198-208, 1977.

STOER, Stephen R; MAGALHÃES, António M; RODRIGUES, David. Os lugares da exclusão social: um dispositivo de diferenciação pedagógica. São Paulo: Cortez, 2004. 150 p.

VAZ, A.. Futebol e representações de gênero: engendrando ações afirmativas e pedagógicas. In: SOUZA, Adalberto dos Santos. Desafios para uma educação física crítica. São Paulo: Cult, 2005.

VEIGA-NETO, A. Foucault \& a educação. Belo Horizonte: Autêntica, 2004. 